\title{
College students are more bored than college faculty
}

\author{
LAWRENCE WEINSTEIN and LINDA L. COX \\ Marymount College of Kansas, Salina, Kansas
}

\begin{abstract}
College students had significantly lower Purpose-in-Life Test scores (less meaning in their lives) than their professors at both secular and religious institutions. Possible reasons for this difference (e.g., age, current conservative students) are discussed.
\end{abstract}

College student life can indeed be one exciting round of stimulating lectures, enthusiastic friends, daily activities guided by very clear goals and aims, and intense pleasure and satisfaction that leads students toward complete fulfillment, or it can be boring. College students complain: they complain about their lackluster listless lecturers, about having nothing to do out of class, of having no goals or aims, of the repetitiveness of daily events, of their existence being purposeless, and, often, of having discovered no personal mission in life. Consequently, some may turn to drugs.

What college professors think of their lot is a mystery. If their thoughts and feelings about their universities are less than complimentary, they keep them to themselves for fear of reprisals from their deans and/or their students. Faculty often come to their classes, sit their required office hours, and go home. Wives and husbands of faculty may hear of problems at work, but faculty say little outside of home except to peers at work who are confidants: "The students are terrible." "This college could be great if it were not for the dean (department head)." "How am I coming across to the students? Am I popular with all of them out there?" "I just take life easy." Are College Faculty not satisfied with their lives? Do they find the essential element in their daily existence absent? Are they bored?

The literature on life satisfaction, apathy, and boredom has grown to a considerable magnitude. Coffield and Buckalew (1985) reported the amount of apathy present in black university students with the Purpose-in-Life Test (PILT). Coffield (1981) reported boredom levels in white university students. Weinstein and Cox (1987) reported on the degree of feelings of meaninglessness in students attending small colleges. Indeed, college students who use marijuana have even been tested with the PILT (Shean \& Fechtmann, 1971).

No one has looked at how college faculty feels about their (vacuous?) professional existence. Moreover, no evidence exists on how faculty members' life satisfaction compares with that of students. Therefore, the present

\footnotetext{
Requests for reprints should be sent to Lawrence Weinstein, Department of Psychology, Marymount College of Kansas, Box 5050, Salina, KS 67402 .
}

study compared the PILT scores of college faculty with those of college students at both a religious and a secular tertiary institution.

\section{METHOD}

\section{Subjects}

There were 78 students between 18 and 40 years of age who were enrolled in an introductory psychology class at a 2-year secular community college in the midwest. There were also 25 students, matched for the above age range, who were enrolled in an introductory psychology class at a 2-year religious college in the midwest. Additionally, there were 24 faculty members from the secular college, who were between 25 and 58 years of age and who had been teaching for 2 to 40 years. Finally, there were 12 faculty members from the religious college who had the same traits as the secular faculty. All students and all faculty were heterogeneous with respect to professed religious orientation; that is, not all faculty and students at the religious college were of the same religion as the college. They were about equally divided between Catholics and Protestants. At the secular college, faculty and students were also about equally divided between Protestants and Catholics.

\section{Materials}

The PILT (Crumbaugh \& Maholick, 1964) was used. The test consists of 20 questions to be rated on scales from 1 to 7 . The test generally gauges the degree to which a person has a purpose in life or finds meaning in his/her existence. The higher the score, the more purpose one has in one's life. The PILT appears to have construct validity in that results from it concur with Frankl's (1960) notions. Frankl's ideas of logotherapy were taken from existential philosophy, namely, the philosophy that many people today suffer from a feeling of emptiness in life. Moreover, there is evidence that the PILT has concurrent validity.

\section{Procedure}

The PILT was administered en masse to the students from the secular college and en masse to the students from the religious college. The 78 students from the secular institution were selected from a random sample of 100 introductory psychology students so that they were all matched for the age range 18-40 years. The 25 religious college students were randomly chosen from 38 introductory psychology students, matched on the same age range variable. The 24 faculty at the secular college were randomly selected from 33 randomly chosen faculty throughout the college so the relevant age range and years of teaching were present; the same selection procedures were used for the religious college faculty. Faculty members took the PILT individually. All student and faculty subjects were assured of the anonymity of the results.

\section{RESULTS}

A two-way analysis of variance (ANOVA) was used to analyze the PILT scores; there were 2 rows (faculty, stu- 
dent) and 2 columns (secular, religious). The row effect was significant $[F(1,135)=22.44, p<.001]$. The faculty mean was 116.83 , and the student mean was 103.26 . The column effect was not significant, and the row $\times$ column interaction was not significant. An ANOVA was done on the religious college faculty versus the religious college students $[F(1,35)=11.98, p<.01]$; the faculty mean was 116.67 , and the student mean was 100.22 . Finally, an ANOVA on the secular college faculty versus the secular college students was significant $[F(1,100)=12.46$, $p<.001$ ]; the faculty mean was 116.54 , and the student mean was 105.15. Neither the ANOVA on secular college students versus religious college students nor the ANOVA on secular college faculty versus religious college faculty was significant.

\section{DISCUSSION}

Faculty have significantly more meaning in their lives than do students, regardless of whether the faculty and students are at a secular or religious college; that is, faculty at the secular college had significantly higher PILT scores than their students, and the religious college faculty had significantly higher PILT scores than their students. Moreover, the fact that faculty feel that they have more meaning in their lives than do students attending the same institution in no way depends on the secular versus religious nature of the institution (this interaction was not significant). Furthermore, students and faculty at religious tertiary institutions have no more purpose in life than do students and faculty at secular tertiary institutions (the column effect was not significant).

The reasons that faculty feel more existential fullness to their lives than do students are not clear. Our faculty had more years of education than our students, but most research has failed to find a significant years-ofeducation effect with the PILT (e.g., Coffield \& Buckalew, 1986; Meier \& Edwards, 1974). Meier and Edwards demonstrated a significant age effect (13-15 vs. 45-55 years, 17-19 vs. 45-55 years, 17-19 vs.
25-35 years), but our ranges were not represented (18-40 and 25-58). It is quite possible, therefore, that age is at least one variable that would account for these results.

If age indeed accounts for the differences obtained here, it may be that the age difference reflects itself in a group of contemporary young people who are more conservative and more concerned with tangible acquisitions than with satisfying their inner selves or with a vigorous exploration of all that life has to offer. Our older faculty participants may have missed the impact of the conservative rebound from the post-1960s Viet Nam era and may still be operating by more self-directed forces.

Future research should examine 4-year and postgraduate tertiary institutions with subjects matched on several more factors. In the meanwhile, it would appear that midwestern college students do not feel as satisfied with their lives as do their professors.

\section{REFERENCES}

Coffield, K. E. (1981). Student apathy: A comparative study. Teaching of Psychology, 8, 26-28.

Coffield, K. E., \& Buckalew, L. W. (1985). University student apathy: Sex, race and academic class variables. Psychological Record, 35, 459-463.

Coffield, K. E., \& Buckalew, L. W. (1986, summer). Student apathy: An analysis of relevant variables. College Student Journal, 20 , 211-214.

Crumbaugh, J. C., \& Maholick, L. T. (1964). An experimental study in existentialism: The psychometric approach to Frankl's concept of noogenic neurosis. Journal of Clinical Psychology, 20, 200-207.

FraNKL, V. E. (1960). Beyond self-actualization and self-expression. Journal of Existential Psychiatry, 1, 5-20.

Meier, A., \& Edwards, H. (1974). Purpose-in-Life Test: Age and sex differences. Journal of Clinical Psychology, 30, 384-386.

Shean, G. D., \& Fechtmann, F. (1971). Purpose-in-Life scores of student marijuana users. Journal of Clinical Psychology, 27, 112-113.

WeINSTEIN, L., \& Cox, L. L. (1987). "I'm bored!'. Bulletin of the Psychonomic Society, 25, 389-390.

(Manuscript received February 29, 1988.) 